\title{
Extracellular Vesicles and Host-Pathogen Interactions: A Review of Inter-Kingdom Signaling by Small Noncoding RNA
}

\author{
Bruce A. Stanton
}

check for updates

Citation: Stanton, B.A. Extracellular Vesicles and Host-Pathogen Interactions: A Review of Inter-Kingdom Signaling by Small Noncoding RNA. Genes 2021, 12, 1010. https://doi.org/ $10.3390 /$ genes 12071010

Academic Editors: Nicolas Soler and Aurore Gorlas

Received: 8 June 2021

Accepted: 29 June 2021

Published: 30 June 2021

Publisher's Note: MDPI stays neutral with regard to jurisdictional claims in published maps and institutional affiliations.

Copyright: (C) 2021 by the author. Licensee MDPI, Basel, Switzerland. This article is an open access article distributed under the terms and conditions of the Creative Commons Attribution (CC BY) license (https:// creativecommons.org/licenses/by/ $4.0 /)$.
Department of Microbiology and Immunology, Geisel School of Medicine at Dartmouth, Hanover, NH 03755, USA; Bruce.A.Stanton@Dartmouth.edu

\begin{abstract}
The focus of this brief review is to describe the role of noncoding regulatory RNAs, including short RNAs (sRNA), transfer RNA (tRNA) fragments and microRNAs (miRNA) secreted in extracellular vesicles (EVs), in inter-kingdom communication between bacteria and mammalian (human) host cells. Bacteria secrete vesicles that contain noncoding regulatory RNAs, and recent studies have shown that the bacterial vesicles fuse with and deliver regulatory RNAs to host cells, and similar to eukaryotic miRNAs, regulatory RNAs modulate the host immune response to infection. Recent studies have also demonstrated that mammalian cells secrete EVs containing miRNAs that regulate the gut microbiome, biofilm formation and the bacterial response to antibiotics. Thus, as evidence accumulates it is becoming clear that the secretion of noncoding regulatory RNAs and miRNAs in extracellular vesicles is an important mechanism of bidirectional communication between bacteria and mammalian (human) host cells. However, additional research is necessary to elucidate how noncoding regulatory RNAs and miRNA secreted in extracellular vesicles mediate inter-kingdom communication.
\end{abstract}

Keywords: outer membrane vesicles (OMV); extracellular vesicles (EVs); bacterial extracellular vesicles (BEV); small non-coding RNA (sRNA); inter-kingdom communication

\section{Introduction}

Numerous studies have demonstrated that extracellular vesicles (EVs) play an important role in cell-cell signaling in all three domains of life, and that EVs are an important mechanism of intra-kingdom and inter-kingdom communication, including communication between hosts and pathogens (reviewed in [1-13]). The secretion of EVs as a mechanism of intra-kingdom and inter-kingdom communication is evolutionarily conserved, as cells from prokaryotes, plants, and animals release EVs [14-16]. Intercellular communication mediated by EVs is an important aspect of host-pathogen interaction that does not require direct cell-cell contact, since, for example, many bacteria reside in mucus overlying epithelial cells in the gut and lungs $[17,18]$. EVs are spherical, cell-derived fragments $\sim 10 \mathrm{~nm}$ to $1000 \mathrm{~nm}$ in diameter delimited by a lipid bilayer and contain proteins, lipids, nucleic acids and many other cellular constituents [2,8,19-21]. The lipid bilayer protects intravesicular RNA from extra-vesicular RNases, and proteins from extracellular proteases, thereby increasing the biological half-life of the intra-vesicular content $[18,22]$. However, studies have shown that RNA and proteins also decorate the extra-vesicular surface of EVs and have biological activity [23]. EVs have been identified in all biological fluids and organs [24], have long half-lives in blood (30 min to $6 \mathrm{~h}[25,26])$, enter cells by a variety of mechanisms, and once inside target cells, release their contents whereupon proteins, small RNAs (sRNAs), tRNA fragments and microRNAs (miRNAs) regulate recipient cell gene expression and function [1-13]. Currently, eukaryotic EVs are classified into many subgroups, including exosomes, microvesicles, and apoptotic bodies, based on their origin, biogenesis, size ( 10 to $1000 \mathrm{~nm})$ and composition $[10,21,27,28]$. However, at the present time there is no consensus on EV subtypes due to a variety of issues, including the cellular source, overlap in size, composition, the lack of knowledge about their biogenesis, and 
difficultly in isolating specific subtypes [10,27]. The International Society of Extracellular Vesicles recommends the use of the term EVs in publications since most studies do not identify the subtype [21,27-29]. Thus, in this review, the term EVs will be used as a general term to describe vesicles secreted by non-microbial cells. The term outer membrane vesicle (OMV) will be used to describe EVs secreted by Gram-negative bacteria. OMVs are $\sim 10$ to $300 \mathrm{~nm}$ vesicles delimited by the outer membrane of Gram-negative bacteria and their contents include periplasmic and cytoplasmic components, including sRNA, tRNA fragments, DNA, lipids and proteins [18,30-37]. Gram-negative bacteria also secrete outer-inner membrane vesicles (O-IMV), which are delimited by the outer and inner membrane of the bacteria, although secretion of O-IMV represents less that $1 \%$ of the vesicles secreted by Gram-negative bacteria $[38,39]$. The role of O-IMV in interdomain signaling is not clear $[38,39]$. Gram-positive bacteria also secrete EVs, but since Gram-positive bacteria do not contain an outer membrane, these EVs are often described as bacterial extracellular vesicles (bEV or BEV) $[10,19,20,40-46]$. In this review, the terms EVs, OMVs and BEVs will be used to describe EVs secreted by non-microbial cells, Gram-negative bacteria, and Grampositive bacteria, respectively. Many recent studies have shown that OMVs and BEVs secreted by bacteria deliver sRNA and tRNA fragments ( 18 to 50 nucleotides (nt) long) to mammalian (human) cells and, although many details are lacking, it has been suggested that the sRNA and tRNA fragments regulate target cell gene expression by sequestering regulatory proteins and/or by base pairing with target mRNAs [4,18,22,30-32,41,47-56]. sRNAs are heterogeneous in size ( 20 to $500 \mathrm{nt})$ and regulate gene expression by basepairing with the translation initiation region or coding sequence of target mRNAs or by acting as sRNA sponges, which are produced by transgenes and have complementary binding sites to specific miRNAs [13]. tRNAs are $~ 70$ to $100 \mathrm{nt}$ long molecules with highly conserved sequences that form secondary cloverleaf and L-shaped three-dimensional structures [13,57-59]. tRNA fragments have been shown to mediate gene silencing in eukaryotic cells through an argonaute (Ago2)-microRNA-like mechanism and have both negative and positive effects on protein translation [57-59]. Many excellent and comprehensive reviews on EVs, OMVs and BEVs have been published [1-13]. However, very few studies have been published describing the role of extracellular vesicles as a delivery mechanism for sRNA, tRNA fragments and miRNAs to target cells and elucidating the mechanism whereby they mediate inter-kingdom signaling. Thus, in this review, the focus will be on recent studies describing how sRNAs, tRNA fragments and miRNAs secreted inside vesicles mediate host-pathogen interactions between bacteria and mammalian (human) cells. In addition, unresolved issues and research opportunities will be discussed.

\section{Extracellular Vesicles Secreted by Bacteria Are Important Mediators of Inter-Kingdom Communication and Deliver sRNA and tRNA Fragments to the Mammalian Host}

OMVs and BEVs secreted by microbes serve a variety of intra-kingdom functions, including horizontal gene transfer, quorum sensing, biofilm formation, pathogenicity, depredation, antibiotic resistance, defense, and nutrient acquisition [1-12,38,60,61]. Similar to miRNAs, every bacterial sRNA and tRNA fragment is predicted to have multiple targets, can regulate genes in cis and trans, modulates transcription and translation, and affects mRNA stability [2]. Although, unlike eukaryotes, bacteria do not have a sRNA-mRNAinduced silencing complex (RISC). The Hfq protein in bacteria stabilizes and presents sRNAs to mRNA by a mechanism that resembles RISC in eukaryotes [2].

OMVs and BEVs mediate the inter-kingdom transfer of sRNA and tRNA fragments between bacteria and mammalian cells without requiring direct contact [4,30-32,41,47-56]. For example, Pseudomonas aeruginosa, residing in the mucus layer overlying lung epithelial cells, secretes OMVs that diffuse through the mucus, fuse with lipid rafts in the apical membrane of airway epithelial cells and deliver a $23 \mathrm{nt}$ tRNA fragment (sRNA-52320) into host cells. sRNA-52320 suppresses the immune response to bacterial infection by targeting several genes in the LPS stimulated MAPK signaling pathway, thereby reducing IL-8 secretion and the migration of neutrophils into the lungs of mice (Figure 1) [18,36,56,62]. Thus, sRNA-52320 is predicted to facilitate the ability of P. aeruginosa to establish a chronic 
lung infection in immunocompromised individuals [18]. sRNAs secreted in OMVs by Aggregatibacter actinomycetemcomitans, a periodontic pathogen, can cross the blood-brain barrier, and sRNAs in the OMVs stimulate TNF-a production by activating the NF- $\mathrm{KB}$ signaling pathways in macrophages, promoting the secretion of pro-inflammatory cytokines in the brain [63-65]. sRNAs in OMVs secreted by Escherichia coli are transferred into bladder epithelial cells and suppress LPS-induced IL-1a secretion [66]. In E. coli OMVs, over 90\% of sequence reads are mapped to tRNA fragments, which are differentially packaged [67]. Listeria monocytogenes secretes OMVs containing the sRNA rli32 that stimulates IFN- $\beta$ production in bone marrow derived macrophages, thereby promoting the intracellular growth of the pathogen [68,69]. Two sRNAs (sR-2509025 and sR-989262) secreted by Helicobacter pylori in OMVs reduce LPS-stimulated IL-8 secretion by human gastric adenocarcinoma cells in culture [70]. Although the mechanism whereby bacterial-derived sRNAs regulate gene expression in eukaryotic host cells is not well characterized, several studies suggest that prokaryotic sRNAs use Ago2 to enhance binding to mRNA targets [71,72]. For example, the intracellular pathogen Mycobacterium marinum infects human THP-1 macrophage cells and secretes a $\sim 23$-nt sRNA that binds to the host RNA-induced silencing complex (RISC) and interferes with gene expression [72]. In addition, Salmonella secretes numerous sRNAs into the cytosol of infected human intestinal epithelial cells, and within the host cell the sRNAs are processed into $\sim 22 \mathrm{nt}$ fragments by the Ago2-based non-classical miRNA processing machinery [71]. One sRNA, Sal-1, facilitates the intracellular survival of Salmonella in infected cells [71].

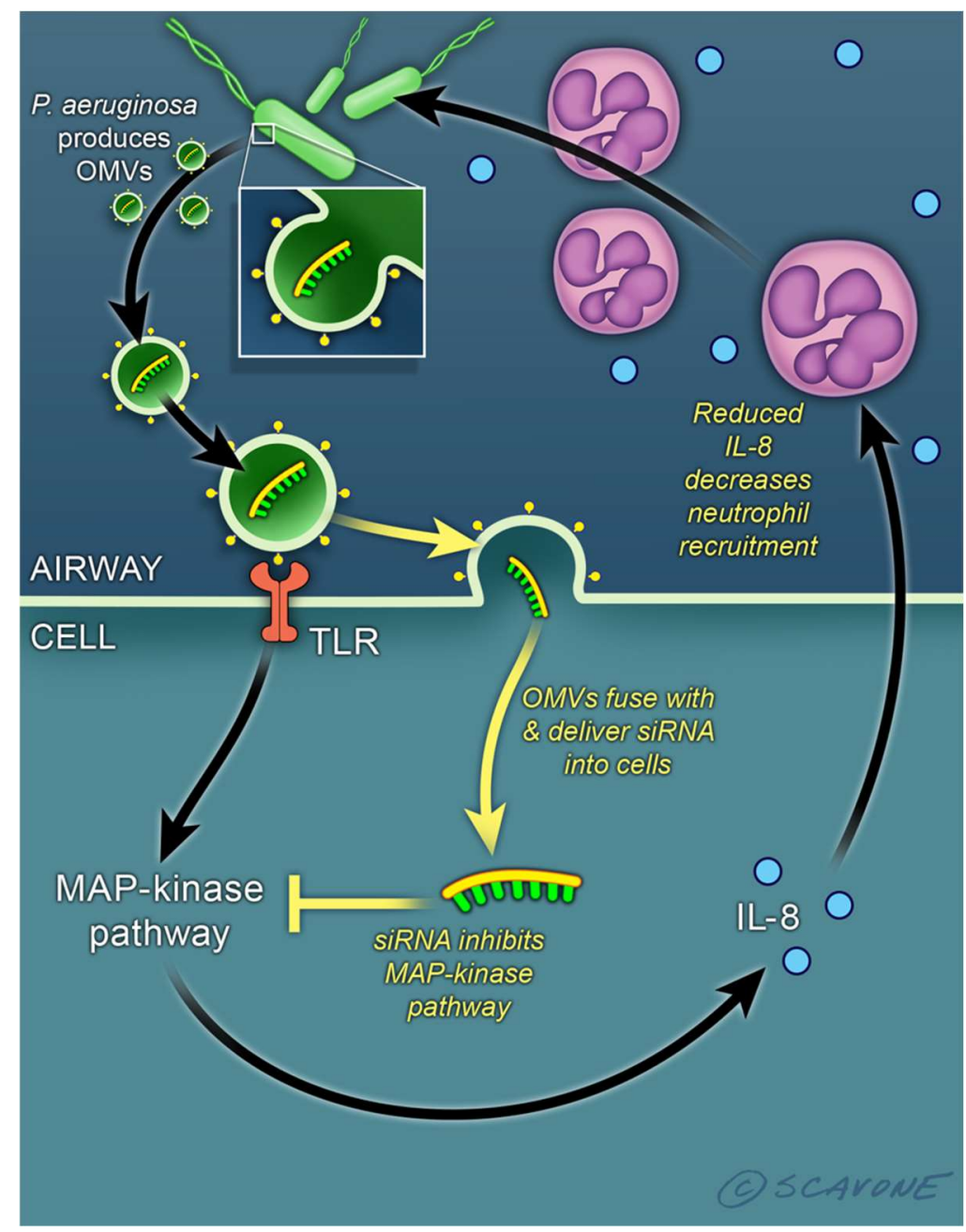

Figure 1. An sRNA (short RNA) secreted in OMVs (outer membrane vesicles) by P. aeruginosa suppresses the host immune response. P. aeruginosa, residing in mucus overlying lung epithelial cells, 
secretes OMVs containing sRNA52320, a 23 nt tRNA fragment. OMVs fuse with cholesterol-rich lipid rafts in the apical membrane of airway epithelia cells, and deliver sRNA52320, which reduces the expression of several genes in the LPS stimulated MAPK pathway, thereby reducing IL- 8 secretion and the migration of neutrophils into the lungs of mice $[18,36,56,62]$. Since neutrophils kill $P$. aeruginosa, it is proposed that the secretion of sRNA52320 in OMVs is a mechanism to reduce neutrophil mediated killing of $P$. aeruginosa, thereby enabling $P$. aeruginosa to establish/maintain chronic infection in immunocompromised individuals.

BEVs ( 20 nm to $400 \mathrm{~nm}$ ) secreted by Gram-positive bacteria also contain sRNAs $(<100 \mathrm{nt}$, with most in the range of 10 to $40 \mathrm{nt})[10,19,20,40-46]$. Although recent studies have shown that sRNAs in BEVs affect host cell biology, to date no studies have identified specific sRNAs that mediate the host response to BEVs. Staphylococcus aureus secretes sRNA and DNA in BEVs that have been implicated in inducing IFN- $\beta$ mRNA by activation of Toll-like receptors in mouse macrophages [41]. S. aureus secrete BEVs that contain immunostimulatory DNA, RNA and peptidoglycan that activate innate immune receptors and induce autophagy in host A549 epithelial cells [40]. Although Mycobacterium tuberculosis (M.tb) is not considered a Gram-positive or Gram-negative bacterium, BEVs secreted by M.tb contain RNAs that promote IFN-b secretion upon entry into RAW 264.7 macrophages, which leads to M.tb clearance via activation of the macrophage RIG-I/MAVS signaling pathway [61]. Importantly, combined treatment with M.tb BEVs and antibiotics decreases bacterial load in a mouse model, reducing lung damage compared to treatment with antibiotics alone [61]. Thus, several studies have demonstrated that Gram-positive bacteria regulate the mammalian (human) host immune response by secreting BEVs containing sRNAs.

\section{Extracellular Vesicles Secreted by Mammalian Cells Are Important Mediators of Intercellular Communication and Delivery of miRNAs to Bacteria}

A few studies have demonstrated that eukaryotic miRNAs ( 22 nt long) affect bacterial gene expression and phenotype $[10-12,27,28]$. Transfection of eukaryotic miRNAs into Fusobacterium nucleatum and E. coli affects mRNA abundance and bacterial growth in the gut [73]. The same research group also found that miR-30d given orally ameliorates autoimmune encephalomyelitis (EAE), a model of multiple sclerosis, by increasing Akkermansia muciniphila abundance in the gut, which leads to an increase in regulatory $\mathrm{T}$ cells that suppress EAE symptoms [74]. None of these studies, however, examined the ability of EVs to deliver miRNAs to bacterial cells. In a recent study, EVs secreted by primary human airway epithelial cells were shown to deliver the miRNA let-7b-5p to $P$. aeruginosa [75]. Moreover, it was demonstrated that let-7b-5p reduced the formation of antibiotic resistant biofilms by decreasing the abundance of several proteins essential for biofilm formation [75] (Figure 2). The effect of let-7b-5p was inhibited by a let-7b-5p antagomir, which blocked the ability of let-7b-5p to bind to target mRNAs. Let-7b-5p was also predicted to target the corresponding biofilm gene orthologs in Burkholderia cenocepacia, another opportunistic lung pathogen, suggesting that the ability of let-7b-5p to reduce biofilm formation and antibiotic sensitivity is not limited to P. aeruginosa [75]. Since several let-7 family members are in clinical trials to reduce inflammation and, because chronic $P$. aeruginosa lung infections are associated with a hyper-inflammatory state, treatment with let-7b-5p and a $\beta$-lactam antibiotic in nanoparticles or EVs may benefit patients with antibiotic-resistant P. aeruginosa infections [75]. Additional studies are required to determine if EVs secreted by other mammalian cells affect bacterial gene expression, how the EVs deliver miRNA to the cytoplasm of bacteria and to elucidate the mechanism whereby a eukaryotic miRNA affects prokaryotic gene expression.

Taken together, the studies described above demonstrate that inter-kingdom communication mediated by sRNA, tRNA fragments and miRNA containing EVs is bi-directional: eukaryotic EVs containing miRNA regulate gene expression in bacteria, and conversely, sRNA and tRNA fragments secreted by OMVs and BEVs affect gene expression and function in eukaryotic cells. However, to date, only one study has shown that EVs secreted by 
mammalian (human) cells deliver a miRNA that directly targets bacterial genes and affects the bacterial phenotype [75].

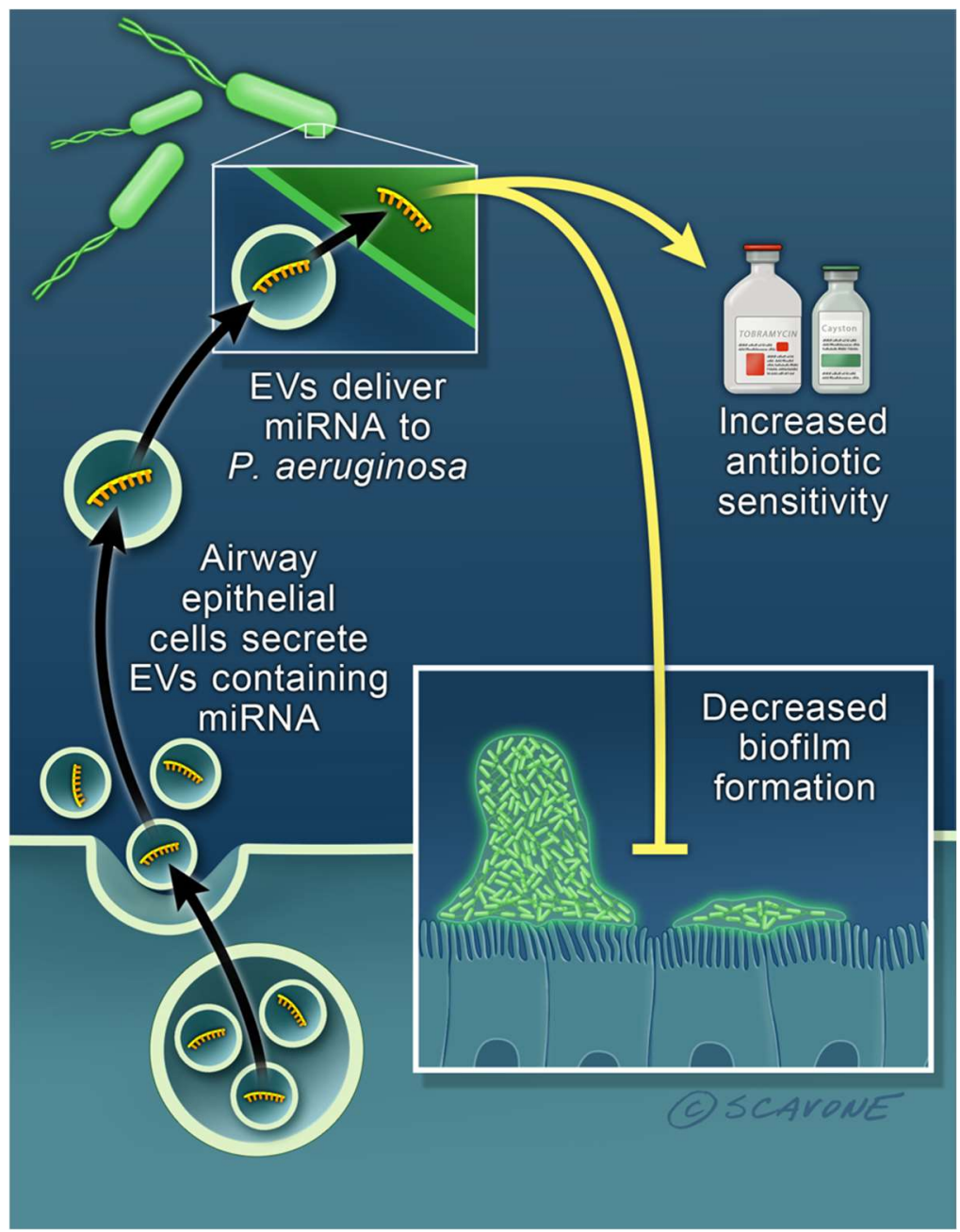

Figure 2. EVs (extracellular vesicles) secreted by mammalian (human) lung epithelial cells contain a miRNA that increase the sensitivity of $P$. aeruginosa to antibiotics and reduces biofilm formation. Airway epithelial cells secrete EVs which deliver the miRNA let-7b-5p to P. aeruginosa. Let-7b$5 p$ reduces the formation of antibiotic resistant $P$. aeruginosa biofilms and increases the ability of antibiotics to kill $P$. aeruginosa. A proteomic analysis of $P$. aeruginosa revealed that let- $7 \mathrm{~b}-5 \mathrm{p}$ increases the ability of $\beta$-lactam antibiotics to reduce biofilm formation by decreasing the abundance of several proteins essential for biofilm formation [75].

\section{Future Prospects}

This brief review has summarized the current state of knowledge regarding our understanding of how small noncoding regulatory RNAs secreted in vesicles mediate inter-kingdom communication between bacteria and mammalian (human) hosts. Several excellent reviews have described how vesicles also mediate signaling between all seven kingdoms of life, including animalia, plantae, and fungi, etc. [2,7,11,12]. However, many aspects of inter-kingdom communication by small regulatory RNAs in vesicles are either poorly understood or unknown and require additional study. For example, the effect of growth conditions, temperature, and antibiotics on vesicle secretion and small regulatory RNA content of OMVs and BEVs are not well understood [22,44,51,76,77]. A few studies have shown that small regulatory RNAs are differentially packaged in vesicles and that the sRNA content of BEVs and OMVs is dependent on growth conditions and antibiotics $[22,44,51,76]$. Thus, additional studies are required to determine the effect of growth 
conditions and antibiotics on RNA content of bacterial vesicles, as well as the effect of polymicrobial infections on RNA content of OMVs and BEVs, and how these factors affect the host response to OMVs and BEVs. In addition, the mechanism whereby noncoding regulatory RNAs affect inter-kingdom communication is also not well understood [78]. At least two mechanisms may be used by noncoding regulatory RNAs to mediate interkingdom communication [11]. First, RNA molecules secreted by one organism could integrate into the regulatory RNA pathway present in the other. As noted above, RNAs secreted by Salmonella and E. coli are processed in eukaryotic cells by the RISC complex, but details are unknown $[71,79]$. Second, some regulatory RNAs are exported in vesicles containing the molecules required for their activity in the recipient cell. For example, Hfq is exported in OMVs secreted by Yersinia pestis [76]. Moreover, little is known about the mechanism whereby EVs deliver small regulatory RNAs to bacteria, and very few studies have unambiguously elucidated the specific gene targets and mechanisms whereby small regulatory RNAs affect gene expression in target cells. Additional studies are also required to explore the use of EVs to prevent the formation of multidrug resistant biofilms [75]. The use of EVs as immunotheropeutics and as diagnostic tools for infectious disease also warrant additional research. It should also be noted that vesicles contain other constituents including proteins and virulence factors that mediate host-pathogen interactions [36,80]. Based on presentations at recent international meetings, including the International Society of Extracellular Vesicles 2021 meeting, many of these issues, and more, are being studied. Thus, the future of research in this exciting field of inter-kingdom communication by regulatory RNAs secreted in vesicles is likely to produce many novel insights, which could lead to the development of therapeutics using small regulatory RNAs to treat bacterial infections and reduce bacteria-induced inflammation in the host.

Funding: The author is supported by the National Institutes of Health (R01 HL151385 and P30 DK117469), and the Cystic Fibrosis Foundation (STANTO19R0, STANTO16GO and STANTO20PO). Any opinions, findings, and conclusions or recommendations expressed in this review are those of the author and do not necessarily reflect the views of the NIH or Cystic Fibrosis Foundation.

Acknowledgments: I thank my colleagues who have contributed to the intellectual and technical development of our research on OMVs and EVs. I also thank Bill Scavone at Kestral Studio for the figures and Katja Koeppen, for comments on this manuscript. Due to the narrow focus of this review, many studies on inter-kingdom communication via small noncoding RNAs could not be cited.

Conflicts of Interest: The author declares no conflict of interest.

\section{References}

1. Nahui Palomino, R.A.; Vanpouille, C.; Costantini, P.E.; Margolis, L. Microbiota-host communications: Bacterial extracellular vesicles as a common language. PLoS Pathog. 2021, 17, e1009508. [CrossRef]

2. Diallo, I.; Provost, P. RNA-Sequencing Analyses of Small Bacterial RNAs and their Emergence as Virulence Factors in HostPathogen Interactions. Int. J. Mol. Sci. 2020, 21, 1627. [CrossRef]

3. Westermann, A.J.; Vogel, J. Cross-species RNA-seq for deciphering host-microbe interactions. Nat. Rev. Genet. 2021. [CrossRef]

4. Ahmadi Badi, S.; Bruno, S.P.; Moshiri, A.; Tarashi, S.; Siadat, S.D.; Masotti, A. Small RNAs in Outer Membrane Vesicles and Their Function in Host-Microbe Interactions. Front. Microbiol. 2020, 11, 1209. [CrossRef]

5. Lee, H.J. Microbe-Host Communication by Small RNAs in Extracellular Vesicles: Vehicles for Transkingdom RNA Transportation. Int. J. Mol. Sci. 2019, 20, 1487. [CrossRef]

6. Vitse, J.; Devreese, B. The Contribution of Membrane Vesicles to Bacterial Pathogenicity in Cystic Fibrosis Infections and Healthcare Associated Pneumonia. Front. Microbiol. 2020, 11, 630. [CrossRef]

7. Lecrivain, A.L.; Beckmann, B.M. Bacterial RNA in extracellular vesicles: A new regulator of host-pathogen interactions? Biochim. Biophys. Acta Gene Regul. Mech. 2020, 1863, 194519. [CrossRef]

8. Briaud, P.; Carroll, R.K. Extracellular Vesicle Biogenesis and Functions in Gram-Positive Bacteria. Infect. Immun. 2020, 88. [CrossRef]

9. Pita, T.; Feliciano, J.R.; Leitao, J.H. Extracellular RNAs in Bacterial Infections: From Emerging Key Players on Host-Pathogen Interactions to Exploitable Biomarkers and Therapeutic Targets. Int. J. Mol. Sci. 2020, 21, 9634. [CrossRef]

10. Munhoz da Rocha, I.F.; Amatuzzi, R.F.; Lucena, A.C.R.; Faoro, H.; Alves, L.R. Cross-Kingdom Extracellular Vesicles EV-RNA Communication as a Mechanism for Host-Pathogen Interaction. Front. Cell Infect. Microbiol. 2020, 10, 593160. [CrossRef] 
11. Layton, E.; Fairhurst, A.M.; Griffiths-Jones, S.; Grencis, R.K.; Roberts, I.S. Regulatory RNAs: A Universal Language for InterDomain Communication. Int. J. Mol. Sci. 2020, 21, 8919. [CrossRef]

12. White, J.R.; Dauros-Singorenko, P.; Hong, J.; Vanholsbeeck, F.; Phillips, A.; Swift, S. The complex, bidirectional role of extracellular vesicles in infection. Biochem. Soc. Trans. 2021. [CrossRef]

13. Li, Z.; Stanton, B.A. tRNA-derived fragments, the underappreciated regulatory small RNAs in microbial pathogenesis. Front. Microbiol. 2021, in press. [CrossRef]

14. Deatherage, B.L.; Cookson, B.T. Membrane vesicle release in bacteria, eukaryotes, and archaea: A conserved yet underappreciated aspect of microbial life. Infect. Immun. 2012, 80, 1948-1957. [CrossRef]

15. Gill, S.; Catchpole, R.; Forterre, P. Extracellular membrane vesicles in the three domains of life and beyond. FEMS Microbiol. Rev. 2019, 43, 273-303. [CrossRef]

16. Woith, E.; Fuhrmann, G.; Melzig, M.F. Extracellular Vesicles-Connecting Kingdoms. Int. J. Mol. Sci. 2019, 20, 5695. [CrossRef]

17. Yanez-Mo, M.; Siljander, P.R.; Andreu, Z.; Zavec, A.B.; Borras, F.E.; Buzas, E.I.; Buzas, K.; Casal, E.; Cappello, F.; Carvalho, J.; et al. Biological properties of extracellular vesicles and their physiological functions. J. Extracell. Vesicles 2015, 4, 27066. [CrossRef]

18. Koeppen, K.; Hampton, T.H.; Jarek, M.; Scharfe, M.; Gerber, S.A.; Mielcarz, D.W.; Demers, E.G.; Dolben, E.L.; Hammond, J.H.; Hogan, D.A.; et al. A Novel Mechanism of Host-Pathogen Interaction through sRNA in Bacterial Outer Membrane Vesicles. PLoS Pathog. 2016, 12, e1005672. [CrossRef] [PubMed]

19. Resch, U.; Tsatsaronis, J.A.; Le Rhun, A.; Stubiger, G.; Rohde, M.; Kasvandik, S.; Holzmeister, S.; Tinnefeld, P.; Wai, S.N.; Charpentier, E. A Two-Component Regulatory System Impacts Extracellular Membrane-Derived Vesicle Production in Group A Streptococcus. MBio 2016, 7. [CrossRef]

20. Joshi, B.; Singh, B.; Nadeem, A.; Askarian, F.; Wai, S.N.; Johannessen, M.; Hegstad, K. Transcriptome Profiling of Staphylococcus aureus Associated Extracellular Vesicles Reveals Presence of Small RNA-Cargo. Front. Mol. Biosci. 2020, 7, 566207. [CrossRef]

21. Toyofuku, M.; Nomura, N.; Eberl, L. Types and origins of bacterial membrane vesicles. Nat. Rev. Microbiol. 2019, 17, 13-24. [CrossRef]

22. Perez-Cruz, C.; Brianso, F.; Sonnleitner, E.; Blasi, U.; Mercade, E. RNA release via membrane vesicles in Pseudomonas aeruginosa PAO1 is associated with the growth phase. Environ. Microbiol. 2021. [CrossRef] [PubMed]

23. Hendricks, M.R.; Lane, S.; Melvin, J.A.; Ouyang, Y.; Stolz, D.B.; Williams, J.V.; Sadovsky, Y.; Bomberger, J.M. Extracellular vesicles promote transkingdom nutrient transfer during viral-bacterial co-infection. Cell Rep. 2021, 34, 108672. [CrossRef]

24. Monguio-Tortajada, M.; Moron-Font, M.; Gamez-Valero, A.; Carreras-Planella, L.; Borras, F.E.; Franquesa, M. Extracellular-Vesicle Isolation from Different Biological Fluids by Size-Exclusion Chromatography. Curr. Protoc. Stem Cell Biol. 2019, 49, e82. [CrossRef]

25. Enaud, R.; Prevel, R.; Ciarlo, E.; Beaufils, F.; Wieers, G.; Guery, B.; Delhaes, L. The Gut-Lung Axis in Health and Respiratory Diseases: A Place for Inter-Organ and Inter-Kingdom Crosstalks. Front. Cell Infect. Microbiol. 2020, 10, 9. [CrossRef]

26. Dang, A.T.; Marsland, B.J. Microbes, metabolites, and the gut-lung axis. Mucosal Immunol. 2019, 12, 843-850. [CrossRef]

27. Théry, C.; Witwer, K.W.; Aikawa, E.; Alcaraz, M.J.; Anderson, J.D.; Andriantsitohaina, R.; Antoniou, A.; Arab, T.; Archer, F.; Atkin-Smith, G.K.; et al. Minimal information for studies of extracellular vesicles 2018 (MISEV2018): A position statement of the International Society for Extracellular Vesicles and update of the MISEV2014 guidelines. J. Extracell. Vesicles 2018, 23, 1535750. [CrossRef]

28. Mathieu, M.; Martin-Jaular, L.; Lavieu, G.; Thery, C. Specificities of secretion and uptake of exosomes and other extracellular vesicles for cell-to-cell communication. Nat. Cell Biol. 2019, 21, 9-17. [CrossRef]

29. Lotvall, J.; Hill, A.F.; Hochberg, F.; Buzas, E.I.; Di Vizio, D.; Gardiner, C.; Gho, Y.S.; Kurochkin, I.V.; Mathivanan, S.; Quesenberry, P.; et al. Minimal experimental requirements for definition of extracellular vesicles and their functions: A position statement from the International Society for Extracellular Vesicles. J. Extracell. Vesicles 2014, 3, 26913. [CrossRef]

30. Elmi, A.; Watson, E.; Sandu, P.; Gundogdu, O.; Mills, D.C.; Inglis, N.F.; Manson, E.; Imrie, L.; Bajaj-Elliott, M.; Wren, B.W.; et al. Campylobacter jejuni outer membrane vesicles play an important role in bacterial interactions with human intestinal epithelial cells. Infect. Immun. 2012, 80, 4089-4098. [CrossRef] [PubMed]

31. Sharpe, S.W.; Kuehn, M.J.; Mason, K.M. Elicitation of epithelial cell-derived immune effectors by outer membrane vesicles of nontypeable Haemophilus influenzae. Infect. Immun. 2011, 79, 4361-4369. [CrossRef]

32. Zhao, K.; Deng, X.; He, C.; Yue, B.; Wu, M. Pseudomonas aeruginosa outer membrane vesicles modulate host immune responses by targeting the Toll-like receptor 4 signaling pathway. Infect. Immun. 2013, 81, 4509-4518. [CrossRef]

33. Tan, T.T.; Morgelin, M.; Forsgren, A.; Riesbeck, K. Haemophilus influenzae survival during complement-mediated attacks is promoted by Moraxella catarrhalis outer membrane vesicles. J. Infect. Dis. 2007, 195, 1661-1670. [CrossRef]

34. Fiocca, R.; Necchi, V.; Sommi, P.; Ricci, V.; Telford, J.; Cover, T.L.; Solcia, E. Release of Helicobacter pylori vacuolating cytotoxin by both a specific secretion pathway and budding of outer membrane vesicles. Uptake of released toxin and vesicles by gastric epithelium. J. Pathol. 1999, 188, 220-226. [CrossRef]

35. Bomberger, J.M.; Maceachran, D.P.; Coutermarsh, B.A.; Ye, S.; O’Toole, G.A.; Stanton, B.A. Long-distance delivery of bacterial virulence factors by Pseudomonas aeruginosa outer membrane vesicles. PLoS Pathog. 2009, 5, e1000382. [CrossRef]

36. Bomberger, J.M.; Ye, S.; Maceachran, D.P.; Koeppen, K.; Barnaby, R.L.; O’Toole, G.A.; Stanton, B.A. A Pseudomonas aeruginosa toxin that hijacks the host ubiquitin proteolytic system. PLoS Pathog. 2011, 7, e1001325. [CrossRef]

37. Stanton, B.A. Effects of Pseudomonas aeruginosa on CFTR chloride secretion and the host immune response. Am. J. Physiol. Cell Physiol. 2017, 312, C357-C366. [CrossRef] 
38. Perez-Cruz, C.; Delgado, L.; Lopez-Iglesias, C.; Mercade, E. Outer-inner membrane vesicles naturally secreted by gram-negative pathogenic bacteria. PLOS ONE 2015, 10, e0116896. [CrossRef] [PubMed]

39. Delgado, L.; Baeza, N.; Perez-Cruz, C.; Lopez-Iglesias, C.; Mercade, E. Cryo-transmission Electron Microscopy of Outer-inner Membrane Vesicles Naturally Secreted by Gram-negative Pathogenic Bacteria. Bio Protoc. 2019, 9, e3367. [CrossRef] [PubMed]

40. Bitto, N.J.; Cheng, L.; Johnston, E.L.; Pathirana, R.; Phan, T.K.; Poon, I.K.H.; O’Brien-Simpson, N.M.; Hill, A.F.; Stinear, T.P.; Kaparakis-Liaskos, M. Staphylococcus aureus membrane vesicles contain immunostimulatory DNA, RNA and peptidoglycan that activate innate immune receptors and induce autophagy. J. Extracell Vesicles 2021, 10, e12080. [CrossRef] [PubMed]

41. Rodriguez, B.V.; Kuehn, M.J. Staphylococcus aureus secretes immunomodulatory RNA and DNA via membrane vesicles. Sci. Rep. 2020, 10, 18293. [CrossRef] [PubMed]

42. Liao, S.; Klein, M.I.; Heim, K.P.; Fan, Y.; Bitoun, J.P.; Ahn, S.J.; Burne, R.A.; Koo, H.; Brady, L.J.; Wen, Z.T. Streptococcus mutans extracellular DNA is upregulated during growth in biofilms, actively released via membrane vesicles, and influenced by components of the protein secretion machinery. J. Bacteriol. 2014, 196, 2355-2366. [CrossRef] [PubMed]

43. Surve, M.V.; Anil, A.; Kamath, K.G.; Bhutda, S.; Sthanam, L.K.; Pradhan, A.; Srivastava, R.; Basu, B.; Dutta, S.; Sen, S.; et al. Membrane Vesicles of Group B Streptococcus Disrupt Feto-Maternal Barrier Leading to Preterm Birth. PLoS Pathog. 2016, 12, e1005816. [CrossRef]

44. Luz, B.; Nicolas, A.; Chabelskaya, S.; Rodovalho, V.R.; Le Loir, Y.; Azevedo, V.A.C.; Felden, B.; Guedon, E. Environmental Plasticity of the RNA Content of Staphylococcus aureus Extracellular Vesicles. Front. Microbiol. 2021, 12, 634226. [CrossRef]

45. Choi, J.W.; Kwon, T.Y.; Hong, S.H.; Lee, H.J. Isolation and Characterization of a microRNA-size Secretable Small RNA in Streptococcus sanguinis. Cell Biochem. Biophys. 2018, 76, 293-301. [CrossRef]

46. Bose, S.; Aggarwal, S.; Singh, D.V.; Acharya, N. Extracellular vesicles: An emerging platform in gram-positive bacteria. Microbe Cell 2020, 7, 312-322. [CrossRef]

47. Wang, Y.F.; Fu, J. Secretory and circulating bacterial small RNAs: A mini-review of the literature. ExRNA 2019, 1. [CrossRef]

48. Zingl, F.G.; Kohl, P.; Cakar, F.; Leitner, D.R.; Mitterer, F.; Bonnington, K.E.; Rechberger, G.N.; Kuehn, M.J.; Guan, Z.; Reidl, J.; et al. Outer Membrane Vesiculation Facilitates Surface Exchange and In Vivo Adaptation of Vibrio cholerae. Cell Host Microbe 2020, 27, 225-237.e228. [CrossRef] [PubMed]

49. Kadurugamuwa, J.L.; Beveridge, T.J. Virulence factors are released from Pseudomonas aeruginosa in association with membrane vesicles during normal growth and exposure to gentamicin: A novel mechanism of enzyme secretion. J. Bacteriol. 1995, 177, 3998-4008. [CrossRef]

50. Hodges, K.; Hecht, G. Interspecies communication in the gut, from bacterial delivery to host-cell response. J. Physiol. 2012, 590, 433-440. [CrossRef]

51. Macdonald, I.A.; Kuehn, M.J. Stress-induced outer membrane vesicle production by Pseudomonas aeruginosa. J. Bacteriol. 2013, 195, 2971-2981. [CrossRef]

52. Wessel, A.K.; Liew, J.; Kwon, T.; Marcotte, E.M.; Whiteley, M. Role of Pseudomonas aeruginosa peptidoglycan-associated outer membrane proteins in vesicle formation. J. Bacteriol. 2013, 195, 213-219. [CrossRef] [PubMed]

53. Maredia, R.; Devineni, N.; Lentz, P.; Dallo, S.F.; Yu, J.; Guentzel, N.; Chambers, J.; Arulanandam, B.; Haskins, W.E.; Weitao, T. Vesiculation from Pseudomonas aeruginosa under SOS. Sci. World J. 2012, 2012, 402919. [CrossRef] [PubMed]

54. Schertzer, J.W.; Whiteley, M. A bilayer-couple model of bacterial outer membrane vesicle biogenesis. MBio 2012, 3. [CrossRef] [PubMed]

55. Hendricks, M.R.; Bomberger, J.M. Who's really in control: Microbial regulation of protein trafficking in the epithelium. Am. J. Physiol. Cell Physiol. 2014, 306, C187-C197. [CrossRef] [PubMed]

56. Barnaby, R.; Koeppen, K.; Stanton, B.A. Cyclodextrins reduce the ability of Pseudomonas aeruginosa outer-membrane vesicles to reduce CFTR Cl(-) secretion. Am. J. Physiol. Lung Cell Mol. Physiol. 2019, 316, L206-L215. [CrossRef]

57. Maute, R.L.; Schneider, C.; Sumazin, P.; Holmes, A.; Califano, A.; Basso, K.; Dalla-Favera, R. tRNA-derived microRNA modulates proliferation and the DNA damage response and is down-regulated in B cell lymphoma. Proc. Natl. Acad. Sci. USA 2013, 110, 1404-1409. [CrossRef]

58. Yamasaki, S.; Ivanov, P.; Hu, G.F.; Anderson, P. Angiogenin cleaves tRNA and promotes stress-induced translational repression. J. Cell Biol. 2009, 185, 35-42. [CrossRef] [PubMed]

59. Su, Z.; Wilson, B.; Kumar, P.; Dutta, A. Noncanonical Roles of tRNAs: tRNA Fragments and Beyond. Annu. Rev. Genet. 2020, 54, 47-69. [CrossRef]

60. Ho, M.H.; Chen, C.H.; Goodwin, J.S.; Wang, B.Y.; Xie, H. Functional Advantages of Porphyromonas gingivalis Vesicles. PLoS ONE 2015, 10, e0123448. [CrossRef] [PubMed]

61. Cheng, Y.; Schorey, J.S. Extracellular vesicles deliver Mycobacterium RNA to promote host immunity and bacterial killing. EMBO Rep. 2019, 20. [CrossRef]

62. Koeppen, K.; Barnaby, R.; Jackson, A.A.; Gerber, S.A.; Hogan, D.A.; Stanton, B.A. Tobramycin reduces key virulence determinants in the proteome of Pseudomonas aeruginosa outer membrane vesicles. PLoS ONE 2019, 14, e0211290. [CrossRef] [PubMed]

63. Choi, J.W.; Kim, S.C.; Hong, S.H.; Lee, H.J. Secretable Small RNAs via Outer Membrane Vesicles in Periodontal Pathogens. J. Dent. Res. 2017, 96, 458-466. [CrossRef] [PubMed] 
64. Han, E.C.; Choi, S.Y.; Lee, Y.; Park, J.W.; Hong, S.H.; Lee, H.J. Extracellular RNAs in periodontopathogenic outer membrane vesicles promote TNF- $\alpha$ production in human macrophages and cross the blood-brain barrier in mice. FASEB J. 2019, 33, 13412-13422. [CrossRef]

65. Ha, J.Y.; Choi, S.Y.; Lee, J.H.; Hong, S.H.; Lee, H.J. Delivery of Periodontopathogenic Extracellular Vesicles to Brain Monocytes and Microglial IL-6 Promotion by RNA Cargo. Front. Mol. Biosci. 2020, 7, 596366. [CrossRef] [PubMed]

66. Dauros-Singorenko, P.; Hong, J.; Swift, S.; Phillips, A.; Blenkiron, C. Effect of the Extracellular Vesicle RNA Cargo from Uropathogenic Escherichia coli on Bladder Cells. Front. Mol. Biosci. 2020, 7, 580913. [CrossRef]

67. Ghosal, A.; Upadhyaya, B.B.; Fritz, J.V.; Heintz-Buschart, A.; Desai, M.S.; Yusuf, D.; Huang, D.; Baumuratov, A.; Wang, K.; Galas, D.; et al. The extracellular RNA complement of Escherichia coli. Microbiologyopen 2015, 4, 252-266. [CrossRef]

68. Frantz, R.; Teubner, L.; Schultze, T.; La Pietra, L.; Muller, C.; Gwozdzinski, K.; Pillich, H.; Hain, T.; Weber-Gerlach, M.; Panagiotidis, G.D.; et al. The secRNome of Listeria monocytogenes Harbors Small Noncoding RNAs That Are Potent Inducers of $\beta$ Interferon. MBio 2019, 10. [CrossRef]

69. Abdullah, Z.; Schlee, M.; Roth, S.; Mraheil, M.A.; Barchet, W.; Bottcher, J.; Hain, T.; Geiger, S.; Hayakawa, Y.; Fritz, J.H.; et al. RIG-I detects infection with live Listeria by sensing secreted bacterial nucleic acids. EMBO J. 2012, 31, 4153-4164. [CrossRef]

70. Zhang, H.; Zhang, Y.; Song, Z.; Li, R.; Ruan, H.; Liu, Q.; Huang, X. sncRNAs packaged by Helicobacter pylori outer membrane vesicles attenuate IL-8 secretion in human cells. Int. J. Med. Microbiol. 2020, 310, 151356. [CrossRef]

71. Gu, H.; Zhao, C.; Zhang, T.; Liang, H.; Wang, X.M.; Pan, Y.; Chen, X.; Zhao, Q.; Li, D.; Liu, F.; et al. Salmonella produce microRNA-like RNA fragment Sal-1 in the infected cells to facilitate intracellular survival. Sci. Rep. 2017, 7, 2392. [CrossRef]

72. Furuse, Y.; Finethy, R.; Saka, H.A.; Xet-Mull, A.M.; Sisk, D.M.; Smith, K.L.; Lee, S.; Coers, J.; Valdivia, R.H.; Tobin, D.M.; et al. Search for microRNAs expressed by intracellular bacterial pathogens in infected mammalian cells. PLoS ONE 2014, 9, e106434. [CrossRef]

73. Liu, S.; da Cunha, A.P.; Rezende, R.M.; Cialic, R.; Wei, Z.; Bry, L.; Comstock, L.E.; Gandhi, R.; Weiner, H.L. The Host Shapes the Gut Microbiota via Fecal MicroRNA. Cell Host Microbe 2016, 19, 32-43. [CrossRef]

74. Liu, S.; Rezende, R.M.; Moreira, T.G.; Tankou, S.K.; Cox, L.M.; Wu, M.; Song, A.; Dhang, F.H.; Wei, Z.; Costamagna, G.; et al. Oral Administration of miR-30d from Feces of MS Patients Suppresses MS-like Symptoms in Mice by Expanding Akkermansia muciniphila. Cell Host Microbe 2019, 26, 779-794.e778. [CrossRef]

75. Koeppen, K.; Nymon, A.; Barnaby, R.; Bashor, L.; Li, Z.; Hampton, T.H.; Liefeld, A.E.; Kolling, F.W.; LaCroix, I.S.; Gerber, S.A.; et al. Let-7b-5p in vesicles secreted by human airway cells reduces biofilm formation and increases antibiotic sensitivity of $P$. aeruginosa. Proc. Natl. Acad. Sci. USA 2021. submitted for publication.

76. Eddy, J.L.; Gielda, L.M.; Caulfield, A.J.; Rangel, S.M.; Lathem, W.W. Production of outer membrane vesicles by the plague pathogen Yersinia pestis. PLoS ONE 2014, 9, e107002. [CrossRef]

77. Woo, J.H.; Kim, S.; Lee, T.; Lee, J.C.; Shin, J.H. Production of Membrane Vesicles in Listeria monocytogenes Cultured with or without Sub-Inhibitory Concentrations of Antibiotics and Their Innate Immune Responses In Vitro. Genes 2021, 12, 415. [CrossRef]

78. Chen, Y.; Shen, J. Mucosal immunity and tRNA, tRF, and tiRNA. J. Mol. Med. 2021, 99, 47-56. [CrossRef]

79. Liu, H.; Wang, X.; Wang, H.D.; Wu, J.; Ren, J.; Meng, L.; Wu, Q.; Dong, H.; Wu, J.; Kao, T.Y.; et al. Escherichia coli noncoding RNAs can affect gene expression and physiology of Caenorhabditis elegans. Nat. Commun. 2012, 3, 1073. [CrossRef]

80. Fabbiano, F.; Corsi, J.; Gurrieri, E.; Trevisan, C.; Notarangelo, M.; D’Agostino, V.G. RNA packaging into extracellular vesicles: An orchestra of RNA-binding proteins? J. Extracell Vesicles 2020, 10, e12043. [CrossRef] 